T. Dmytrenko, T. Derkach, A. Dmytrenko, L. Klochko

National University «Yuri Kondratyuk Poltava Polytechnic», Poltava, Ukraine

\title{
THE INFORMATION SYSTEM DEVELOPMENT FOR MANAGING THE BUILDING STRUCTURES DEPARTMENT
}

\begin{abstract}
An automated information management system for the higher educational institution department is proposed. To implement the ENQA recommendations at the Computer and Information Technologies Department of the National University "Yuri Kondratyuk Poltava Polytechnic», the task was to create an information system for the unit. The information system will optimize the training procedure, expand the possibilities for analyzing the results, ensure transparency and objectivity in the students training and qualification assessment, which. As a result, will contribute to increasing the citizens' confidence level in higher education. The information system design stages are considered, in which the main technical task sections were drawn up. The information system architecture, the scenario for integrating the system with external software products, initial data sources and options for the initial system content and the access user and administration rights concept and powers have been developed. The department automated information management system functional requirements have been formed. At the stage of information systems designing the main sections of requirements specification have been designed. Being realised, AIS structure corresponds to well-known management control pyramid of the vertical labor division. An information system division has been created to optimize the process of learning, enhance the ability to analyze results, ensure transparency and objectivity in the process of training and qualification assessment of students, as a result, help increase public confidence in higher education.
\end{abstract}

Keywords: ERP - system, ENQA standards, information, information system, distance learning.

\section{Introduction}

One of the promising areas of informatization is the resource management systems development for organizations and enterprises (ERP - systems). Currently, the point issue is the computer support systems construction for university management and the education quality. This problem is dealt with in most countries of the European Union and beyond.

This is due to the constant modernization of national education systems, the Bologna process development, as well as the subject area complexity.

Analysis of recent research and publications. Considering the quality assurance business process in education, we relied on the "Standards and Recommendations for Quality Assurance in Higher Education in the European Space", developed by the European Association for Quality Assurance in Higher Education ENQA on the direct instructions of the Education Ministers Conference of the European countries that signed the Bologna Declaration. The European Association for Quality Assurance in Higher Education (ENQA) is an organization that aims to maintain and increase the quality of European education at a high level [1].

The Standards and Recommendations have the following objectives:

- define a common framework for quality assurance systems for teaching and learning at European, national and university levels;

- create an opportunity to ensure and improve the quality of higher education in the European Higher Education Area;

- support the formation of mutual trust, facilitating recognition and mobility within and beyond national borders;

- provide information on quality assurance in the European Higher Education Area (European Higher Education Area).
- The Standards and Guidelines are based on the following four quality assurance principles for accreditation:

- higher education institutions bear the main responsibility for the quality of their educational services and ensuring this quality;

- the quality assurance system responds to the higher education systems diversity, educational institutions, programs and students;

- the quality assurance system supports the quality culture development;

- the quality assurance system takes into account the needs and expectations of students, all involved parties and society [2, 13].

Purpose of the article. Propose an automated information management system project for a university department that fulfil the criteria: reliability in service and safety; compatibility; ease of use and administration; modularity; access security; the software cost, maintenance and hardware [3].

\section{The main part of the article}

The work analyzed the practical design solutions experience for IMS of universities that successfully implement information systems to automate management processes. Particular attention was paid to the experience analysis, the EU projects TEMPUS INURE and INARM implementation, the introducing information systems practice in European universities $[4]$.

Using the analysis of existing solutions is the ability to plan the creation of both the ISU as a whole, and its individual stages. So at the Belarusian State University, the development process was divided into 12 stages and provided for the release of 4 versions of the ISU. It is important the schedule is drawn up in such a way at each stage the consumer receives a workable IMS prototype. The EU TEMPUS INARM projects have implemented a competency-based approach in 
higher education and the educational descriptors selection. The basis for such decisions is the national qualifications framework approved in Ukraine, the professions classifier, professional standards, as well as educational descriptors at the individual disciplines level. The Dnepropetrovsk National University used a document-oriented approach to the design of IS. At Sumy State University, structural units ratings have been developed as a information component and analytical support for effective university management. Attention is drawn to the student mobile portal implemented at the Dnipropetrovsk National Mining University, which used the experience of the University of Koblenz-Landau (Germany), and also analyzed the operating experience the information system of the Khmelnitsky National University, showed that when placing the main components of the IP (web + database server) on a single server, there are such problems that do not allow providing constant round-the-clock access to the system [4].

In establishing an information portal, generalpurpose CMS and special systems were considered and analyzed, including Wiki-systems, learning content management systems (LCMS), distance learning systems, learning management systems (LMS, LMS, VLS), etc. CMS (WCMS), Web-content management system is software that automates the creating processes and maintaining Web sites. As a software development industry, the design and CMS systems implementation is based on advances in the software systems modeling and development methodology [7-9] and software quality assurance $[10,11]$.

CMS systems include systems such as Drupal, Plone, Joomla, Wordpress. Typo3, 1C-Bitrix, NetCat, DotNetNuke, Mambo.

Adaptive and intelligent learning systems are widely considered in works [7-9].

In the modern information space, there are many distance learning management systems. The most common of them: ATutor, Claroline, Live@ @DU, eFront, Moodle, SharePointLMS (Fig. 1).

The information systems development for distance learning primarily ensures the economic education efficiency and is offered to a wide audience [13].

The distance learning system, which is one of the information system modules "Department's Portal", has a complex structure to ensure interaction between students and teachers [15]. This system is known as the Community of Inquiry (CoI) [14].

According to the ENQA standard, information management is an important element in improving the education quality. Reliable data is essential for making informed decisions and for understanding what is working properly and what needs attention. Effective processes for collecting and analyzing curriculum information and other activities are part of an internal quality assurance system. The nature of the information collected depends to some extent on the type and mission of the institution. In Sovrem particular interest are the following:

- key performance indicators;

- information about students;
- students achievement, progress and elimination indicators;

- the level of student satisfaction with their programs;

- available learning resources and student support services;

- career graduates trajectories.
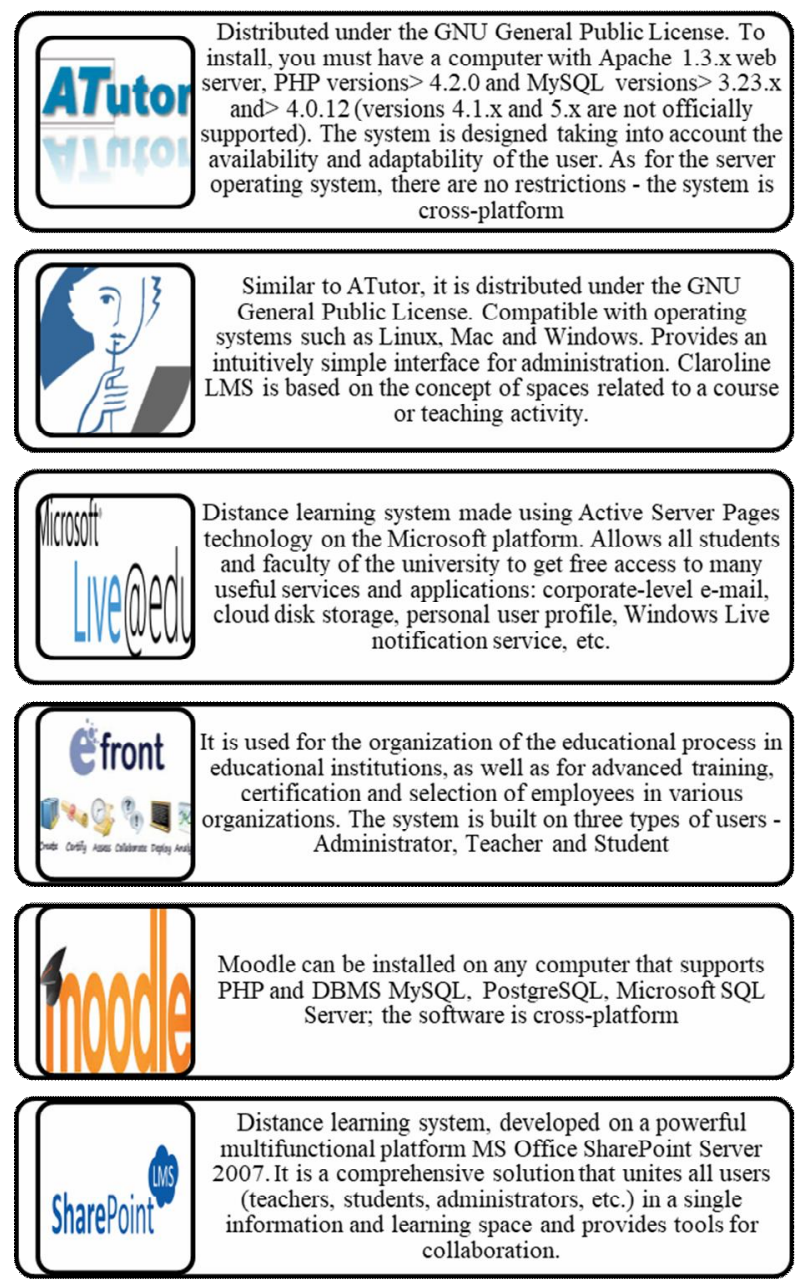

Fig. 1. Comparison of distance learning management systems

Various collecting information methods can be used. It is important that students and staff participate in the provision and information analysis, as well as in the future activities planning [2].

To implement these recommendations at the Department of Computer and Information Technologies of the National University "Yuri Kondratyuk Poltava Polytechnic», the creating an information system task for the unit was set.

The information system will optimize the training procedure, expand opportunities for analyzing results, ensure transparency and objectivity in the training and qualification students assessment, as a result, will help to increase the citizens' confidence level in higher education, as well as automate reporting on methodological and scientific activities of the department teaching staff.

The design elements determine the fundamental points associated with the information system development and implementation (Fig. 2). 


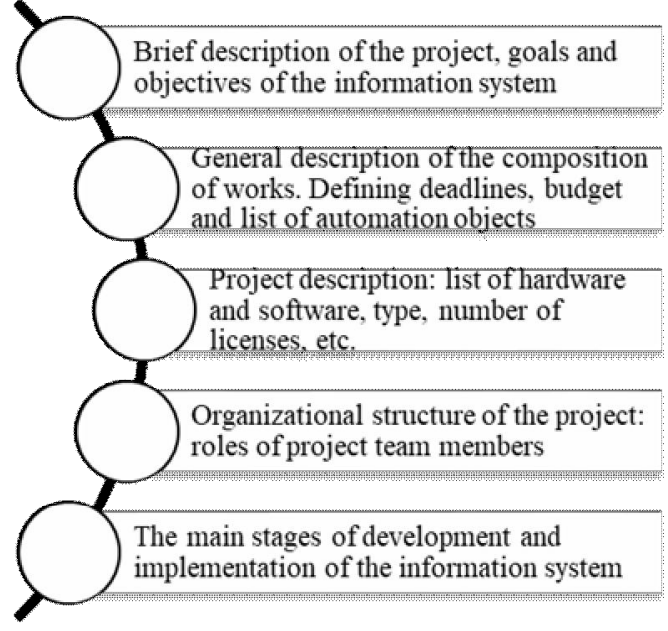

Fig. 2. Design elements

At the information system design stage, the main reference terms sections were drawn up:

- information system architecture;

(database)

a information storage structures description

- design solution, that is, a scenario description for automating the system processes;

- script development for integrating the system with external software products;

- initial data sources and options for the system initial content;

- access rights and power concept development for users and administration.

The system was divided into a number of subprocesses (Fig. 3).

- Control over the development and publication of planned learning outcomes

- Constant control over the development of the curriculum preparation and

content of educational programs

- Control of specific requirements for different types of training (fill-time

distance learning)

- Monitoring the availability of appropriate learning resources

- Control of assessment of students' level of knowledge

- Teaching level control

- Monitoring student performance and achievement

-Participation of students in quality assurance activities

-Quality information contro

- Quality control of quality assessmen

Fig. 3. Subprocesses of the information system

Control over the development and publication of the planned learning outcomes, as well as control over the curriculum development, the drafting and educational programs content involve the draft curriculum submission for discussion by the teaching staff. Based on the discussion results, it is possible to make adjustments.

Monitoring the the students knowledge level assessment is one of the most important processes in assessing the education quality. The assessment results have important implications for the future students careers. So, knowledge should be assessed on a professional basis, taking into account the latest developments in testing and validation. The assessment procedure results show the method effectiveness for assessing the educational process at the university [4].

Given the assessment importance for the students educational advancement and for their future careers, assessment quality assurance procedures should be based on guidelines recommended by ENQA.

Monitoring the teaching level assumes that the unit (department) management must have mechanisms and criteria for assessing the teachers competence. Monitoring the students success and achievements requires a developed monitoring and analysis system.

Quality reporting control is described as a requirement for the up-to-date regular publication, unbiased and objective, quantitative and qualitative information on implemented programs.

In AIS, the structure corresponds to the wellknown management pyramid in the vertical labor division [5]:

1. Subsystem "Department" - a database, a DBMS that automates the collection functions, systematization and primary data processing on the departments and students' activities.

2. Subsystem "Dean's office" - an automated system that monitors the faculty activities based on the data model and system models of the department, teacher, student.

3. Subsystem "Pro-rector" - an automated system for monitoring activities based on models of the faculty, department.

4. Subsystem "University" - DSS, supports the rector (academic council) activities, includes an intelligent software system and experts (advisory council).

The AIS creation is aimed at ensuring control:

- teaching work of teachers (workload: planning, reporting);

- educational students work (progress, attendance, control);

- methodical work (development and accounting of the department disciplines methodological support)

- scientific work (planning, carrying out scientific research);

- educational work (planning and accounting for the department)

- organizational work (planning and accounting for the department, taking into account instructions from the faculty, university).

The automation object is an information system that ensures the higher educational institution department work.

AIS "Information portal of the department", which is implemented as a web application, consists of the main parts:

- public component - the official department website. The main direction is the department achievements presentation on the Internet;

- service component - provides the AIS basic functions; 
- external software interface - designed to integrate AIS with the faculty and university information system.

The functional requirements obtained as the regulatory documents analysis result can be grouped as follows:

1. The subsystem "Planning the educational process" should provide:

- curricula formation and editing. The educational process in Ukraine is regulated by the curriculum with the normative disciplines allocation of and variable part disciplines. Based on the curriculum, taking into account the allocated classroom hours and self-study hours, each teacher develops a work program for the discipline.

This takes into account that the discipline can be divided into meaningful modules, which indicate the topics of the lecture material and practical (laboratory, seminar) classes [6];

- teaching load automatic formation for teachers;

- the ability to manually edit the load on the department;

- the ability to control errors when manually editing the load;

- load data transfer to the individual teacher's plan after its approval;

- planned data introduction into an individual plan of all types of work according to approved standards;

- actual data introduction into an individual plan of all types of work;

- formation of the department work plan;

- teacher's report automatic generation, including the rating.

2. Subsystem "Methodological support" should provide:

- data input on the department disciplines methodological support;

- teaching materials publication in electronic form for general access

- finding means the necessary materials;

- report construction on the disciplines methodological support, specialties.

3. The subsystem "Scientific work" should provide:

- data input on the department faculty scientific activity;

- analysis of the department teachers scientific activities;

- creation of reports on the department scientific activities;

4. The "Remote Support" subsystem should provide:

- adding, entering, editing reference books;

- editing formulas for calculating rating indicators;

- testing students in the above disciplines;

- data export functions.

The "Remote Support" subsystem consists of the system logical structural elements (Fig. 4): administration; testing; practical tasks and lectures; training and metodology complex; data collection; feedback; private office.

To accomplish this task, a well-thought-out and convenient the system file structure was developed.

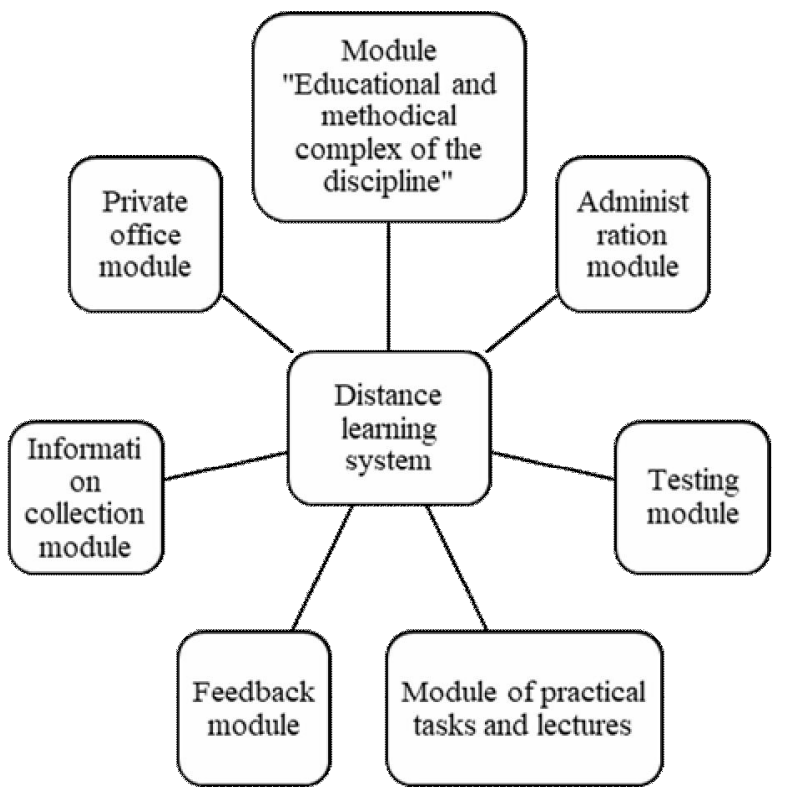

Fig. 4. The LMS logical structure

Based on the analysis of the subject area and regulatory documentation, four main interrelated modules can be distinguished in the AIS structure.

1. The module for planning the educational process is designed to automate such processes.

2. The module for methodological subdivision support is designed to analyze the subdivision activities, generate an automatic report.

3. The module of the division scientific and pedagogical staff activity is designed to automate the forming rating indicators processes and creating reporting information.

4. The remote support module is designed for teachers to work with students remotely.

In the designing process and deploying large hardware and software systems, difficulties always arise while choosing the optimal configuration option for the hardware platform. The difficulty lies in assessing the load on the equipment while using the system by a large users number. The only way to find out how many users a given configuration can handle is to test it on real server hardware. And this already presupposes the equipment availability, that is, its acquisition. What equipment needs to be purchased, in this case, is determined by simple typical calculations and assumptions. This approach cannot guarantee the required performance, and the cause of system failure can be overload, which will be the result of a wrong choice. It is almost impossible to assess the real performance without assessing the particular system response and predicting its behavior under various loads.

To demonstrate the user roles distribution and their capabilities on the site, diagrams were built in the Rational Rose environment.

The conceptual system model is expressed in the use-case diagrams form.

A use cases diagram for the developed system administration is shown in Fig. 5. 
The information system

"Web portal of the department" is implemented in PHP 5.x, MySQL DBMS, Apache web server, Unix - a similar operating system. The users number varies from 300 to 3000 (depends on the disciplines number taught at the department and the students). The main load on the server will be created by the distance education the Department's Web portal subsystem. The peak server load will occur during sessions.

Therefore, to determine the hardware configuration, the peak loads on the information system were determined.

Also, such parameters as the computing cores (processors) number, the amount of RAM, the network channel required bandwidth.

To simplify the calculations, we introduce the following simplifications:

- all requests come from one node, that is, in front of the server it is in front of the router. (In fact, the server is physically located within the local university network)

- the channel bandwidth between the router and the server is maximum, that is, any number of requests pass through the specified interval.

Based on this, the minimum server configuration was calculated [12]: cores number - 4-8, 8 GB of RAM, bandwidth 2-10 Mbit / s, Apache Web server $32 \mathrm{MB}$, DBMS - MySQL 32 MB. by:

Reliable software package functioning is ensured

- control of the initial data correctness and completeness- all data entered by the user are checked for formal correctness;

- keeping user actions records;

- failure recovery - in the software failure event, the system must restore operation from the last recorded stable state.

\section{Conclusions}

The overwhelming free systems (open source) majority are quite difficult to maintain and require highly qualified specialists to implement and support the system.

The research result was an automated information management system for the higher educational institution department.

The module for remote developed information system support provides for the static training courses preparation based on the authorized users' educational needs, the access organization to the course materials, the communication organization between the participants in the educational process, the control with an exam.

At the time of the reporting activities within the scientific framework and methodological work, it was associated with some organizational difficulties (interviewing teachers and students, manually filling in the names of conferences and abstracts).

The solutions we have proposed will optimize the notification system, simplify the reporting organization, and socially draw attention to scientific activities.

A feature of the created system is the ability to create in an automated mode reporting on scientific, scientific, methodological and educational teachers work. The information system makes it possible to analyze the department teaching staff activities, gives recommendations for increasing the implementation of the departments scientific activities planned indicators and university scientific departments.

The system provides the ability to automatically collect information about the h-index and the scientific citations number and pedagogical workers, graduate students and doctoral students by the ID ORCID number of the Google Scholar Citations database.

Most of the information systems for the departments work do not make it possible to create reports on the department activities.

The presented system allows authorized users to enter information about their activities on their own. The system provides the ability to check the entered data.

The subsystem "Planning the educational process" of the educational process management in the developed information system includes the following subprocesses:

- student contingent management;

- formation of educational process curricula (curriculum) and schedules;

- working curricula (syllabus)formation;

- students' individual curricula formation;

- teaching load calculation and distribution; 
- educational process schedule formation;

- keeping an electronic journal;

- learning outcomes

- students and graduates electronic survey;

- employers electronic survey;

- educational process quality control.
Created the unit information system allows you to optimize the training procedure, expand the possibilities for analyzing the results, ensure transparency and objectivity in the training procedure and qualification students assessment, which, as a result, helps to increase the citizens' confidence level in higher education.

\section{REFERENCES}

1. The Standards and guidelines for quality assurance in the European Higher Education Area (ESG). [Електронний ресурс]. Режим доступу: http://www.enqa.eu/index.php/home/ esg (accessed July 20, 2015).

2. Стандарти і рекомендації щодо забезпечення якості в Європейському просторі вищої освіти. [Електронний ресурс]. Режим доступу: http://www.enqa.eu/ndirme/esg/ ESG \%20in \%20 Ukrainian by \% 20the\%20British\%20 Council.pdf

3. Dmytrenko T.A., Dmytrenko A.O., Derkach T.M., Klochko L.A. Scientific and Technical Activities Management Automation of the Department of Structures from Metal, Wood, and Plastics. In: Onyshchenko V., Mammadova G., Sivitska S., Gasimov A. (eds) Proceedings of the 2nd International Conference on Building Innovations. ICBI 2019. Lecture Notes in Civil Engineering, vol 73. Springer, Cham, (2020) https://doi.org/10.1007/978-3-030-42939-3 36

4. Методологические основы создания, внедрения и развития интегрированной информационной M54 системы управления университетом / под ред. С. В. Чернышенко, Ю. И. Воротницкого. - Сумы : Сумский государственный университет, 2015. $-343 \mathrm{c}$.

5. Ashimova D. E. Information system of the results of scientific activities at the University / D.E. Ashimova, A. Zh. Amirov, B. K. Sultanova, D. A. Kabylova // Scientific Almanac, 2016. - № 2 (11). - C. 22-25.

6. Завгородній В. В. Концепція створення єдиного інформаційного освітнього простору України на прикладі дистанційного навчання IT-студентів / В. В. Завгородній, К. М. Ялова // Вісник Кременчуцького національного університету імені Михайла Остроградського. - Кременчук: КрНУ, 2014. - Випуск 2 (85). - С. 112 - 118.

7. Sviridov S. Information and analytical accounting system for the scientific activity of academic institution/ S. Sviridov // First International Conference on Ocean Thermohydromechanics-2017, https://doi.org/10.29006/978-5-9901449-3-4-2017-1144-147, last accessed 2020/05/03.

8. Дмитренко Т.А. Деркач Т.М., Демиденко М. І., Дмитренко А. О Розробка автоматизованої інформаційної системи «Портал кафедри ВНЗ» / Вісник Кременчуцького національного університету імені Михайла Остроградського. Кременчук: КрНУ, 2017. - Випуск 1(102) - С. 32-40.

9. Богомолов А.В. Обзор бесплатных систем управления обучением // Educational Technology \& Society 10 (3). - 2017.

10. Михеев И. В. Система количественных характеристик оценки качества программных продуктов / И. В. Михеев, О. В. Виштак, Д. В. Кондратов // Программные системы и вычислительные методы. - 2018. - №2. - pp. 28-35. URL: https://cyberleninka.ru/article/n/sistema-kolichestvennyh-harakteristik-otsenki-kachestva-programmnyh-produktov （дата обращения: 18.02.2021).

11. De Bra, P. Web-based educational hypermedia/ P. De Bra // Book chapter in: Data Mining in E-Learning / [edited by C. Romero and S. Ventura]. - Universidad de Cordoba, Spain, WIT Press., 2006. - P. 3-17.- ISBN 1-84564-152-3.

12. Лямин А.В., Методика расчета вычислительной мощности програмно-аппаратного комплекса для проведения ЕГЭ в компьютерной форме / А.В. Лямин, А.А. Скшидлевский // Научно -технический вестник СПбГУ ИТМО. - 2008. - № 56. - С. 103-111. [Електронний ресурс]. - Режим доступу: http://ntv.ifmo.ru/file/journal/53.pdf (accessed July 25, 2016).

13. Jie C. Y. Effects of online presence on learning performance in a blog-based online course / C. Y. Jie, Q. Benazir, C. NianShing, M. Qiang // Internet and Higher Education. - 2016. - № 30 - P. 11-20 [Електронний ресурс]. - Режим доступу: http://staff.csie.ncu.edu.tw/yangjc/paper/2016_IntHighEdu_Yang.pdf (accessed October 28, 2016).

14. Dabbagh N. Personal learning environments, social media, and self-regulated learning: A natural formula for connecting formal and informal learning / N. Dabbagh, A. Kitsantas // The Internet and Higher Education. - 2015. - № 15(1). - P. 3 -8.

15. Ekwunife-Orakwue K. C. V. The impact of transactional distance dialogic interactions on student learning outcomes in online and blended environments / K. C. V. Ekwunife-Orakwue, T. L. Teng // Computers \& Education. - 2016. № $78 .-$ P. $414-427$.

Received (Надійшла) 18.11.2020

Accepted for publication (Прийнята до друку) 10.02.2021

\section{Розробка інформаційної системи управління кафедрою «Будівельних конструкцій»}

Т. А. Дмитренко, Т. М. Деркач, А. А. Дмитренко, Л. А. Клочко

Анотація. У даній статті запропоновано автоматизовану інформаційну систему управління кафедрою вищого навчального закладу. Для реалізації рекомендацій ENQA на кафедрі комп'ютерних та інформаційних технологій національного університету «Полтавська політехніка імені Юрія Кондратюка» була поставлена задача створення інформаційної системи підрозділу. Інформаційна система дозволить оптимізувати процедуру проведення навчання, розширить можливості для аналізу результатів, забезпечить прозорість і об'єктивність в процедурі навчання $\mathrm{i}$ кваліфікаційного оцінювання студентів, що, в підсумку, буде сприяти підвищенню рівня довіри громадян до вищої школи. Розглянуто етапи проектування інформаційної системи, в яких були оформлені основні розділи технічного завдання. Розроблено архітектуру інформаційної системи, сценарій інтеграції системи 3 зовнішніми програмними продуктами, джерела вихідних даних і варіанти початкового інформаційного наповнення системи і концепція прав доступу i повноваження користувачів i адміністрування. Сформовано функціональні вимоги автоматизованої інформаційної системи управління кафедрою.

Ключ ов і слов а : ERP - система, стандарти ENQA, інформація, інформаційна система, дистанційне навчання. 